\title{
Closing the Loops in Textile Architecture: Innovative Strategies and Limits of Introducing Biopolymers in Membrane Structures
}

\author{
Alessandra Zanelli, Carol Monticelli and Salvatore Viscuso
}

\begin{abstract}
Biopolymers have been increasingly introduced in some application sectors, such as food packaging, fashion, and design objects, while the typical technical textiles for architecture remain polymeric composites, based on the use of non-renewable resources. In lightweight construction and textile architecture, the introduction of novel materials requires a long process of verification of their performances, in order to guarantee the safety levels required by building standards. The paper aims to focus on potentiality and constrains to the application of more eco-friendly coated textiles, woven, and non-woven membranes in architecture. The paper proposes a couple of strategies and best practices to be applied in lightweight architecture: (1) creating fabrics from recycled fibers, on the one hand, and (2) acting on the coating with biopolymers, on the other hand. Eventually, the paper focuses on some recent experimental research led by the authors at the ABC Department, on the environmental assessment of ultra-lightweight materials, based on the LCA methodology.
\end{abstract}

Keywords Biopolymers · Technical textiles $\cdot$ Lightweight architecture • Eco-efficiency

\section{Textile Industry in a Sustainable Bio-economy}

The textile industry in Europe over the last ten years has shown distinctive development trends for the general textile and leather goods sector and its specific technical textiles subdivision (ExportPlanning 2018). Beside almost imperceptible improvements of the main textile sector, consistent European competitiveness appears in the production of "technical textiles," created by high-tech value-added supply chains, such as automotive, geo-textiles, medical, architecture, furniture, and technical clothing sectors (Fig. 1). The world production of woven and non-woven

\footnotetext{
A. Zanelli $(\bowtie) \cdot$ C. Monticelli $\cdot$ S. Viscuso

Architecture, Built Environment and Construction Engineering-ABC Department, Politecnico di Milano, Milan, Italy

e-mail: alessandra.zanelli@polimi.it
} 


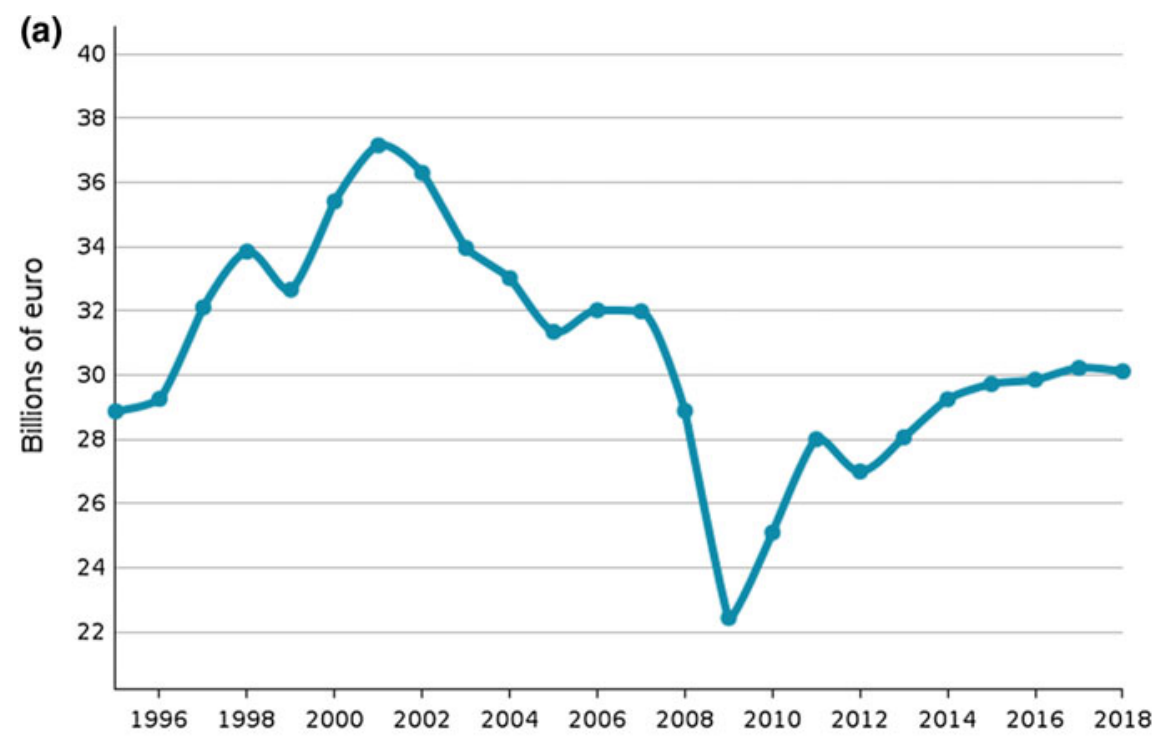

Source: Ulisse Information System

Exporter: E3, Importer: E3, Year: ALL, Price range: TOT, Currency: EUR, Prod: B2

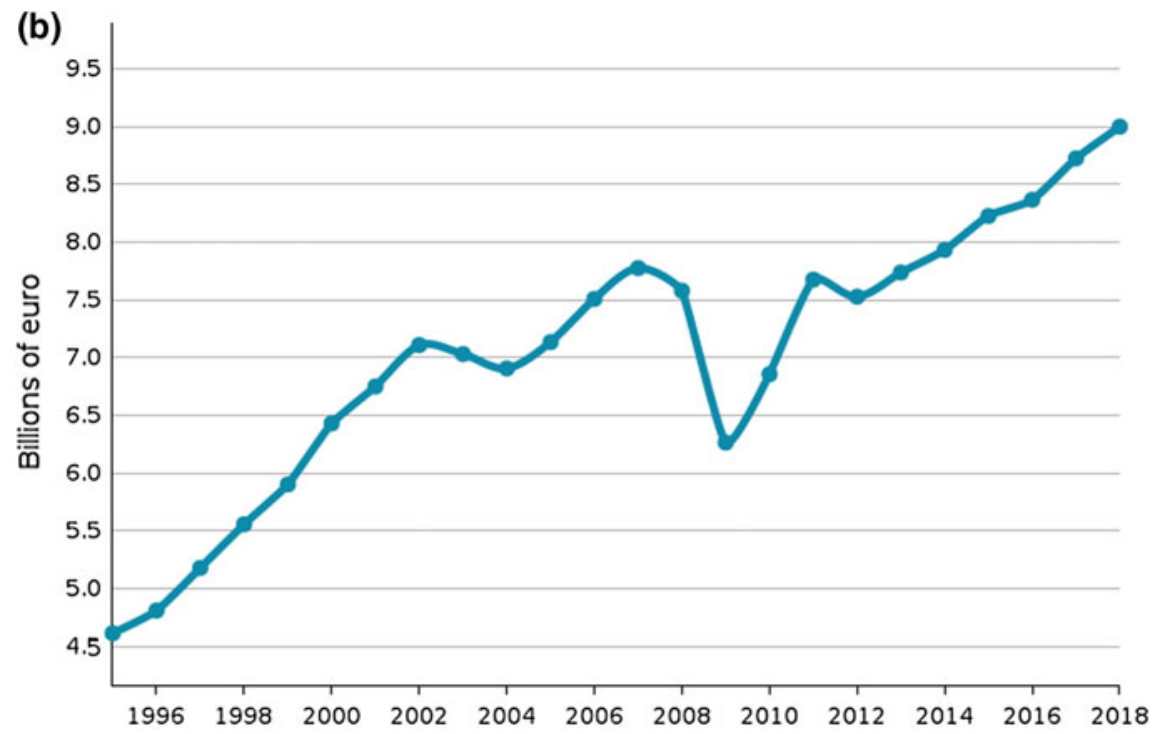

Source: Ulisse Information System

Exporter: E3, Importer: E3, Year: ALL, Price range: TOT, Currency: EUR, Prod: B2.34

Fig. 1 Production trends of the sector of fabric and leather goods (a, left) and its segment of technical textiles (b, right). Source ExportPlanning (2018) 


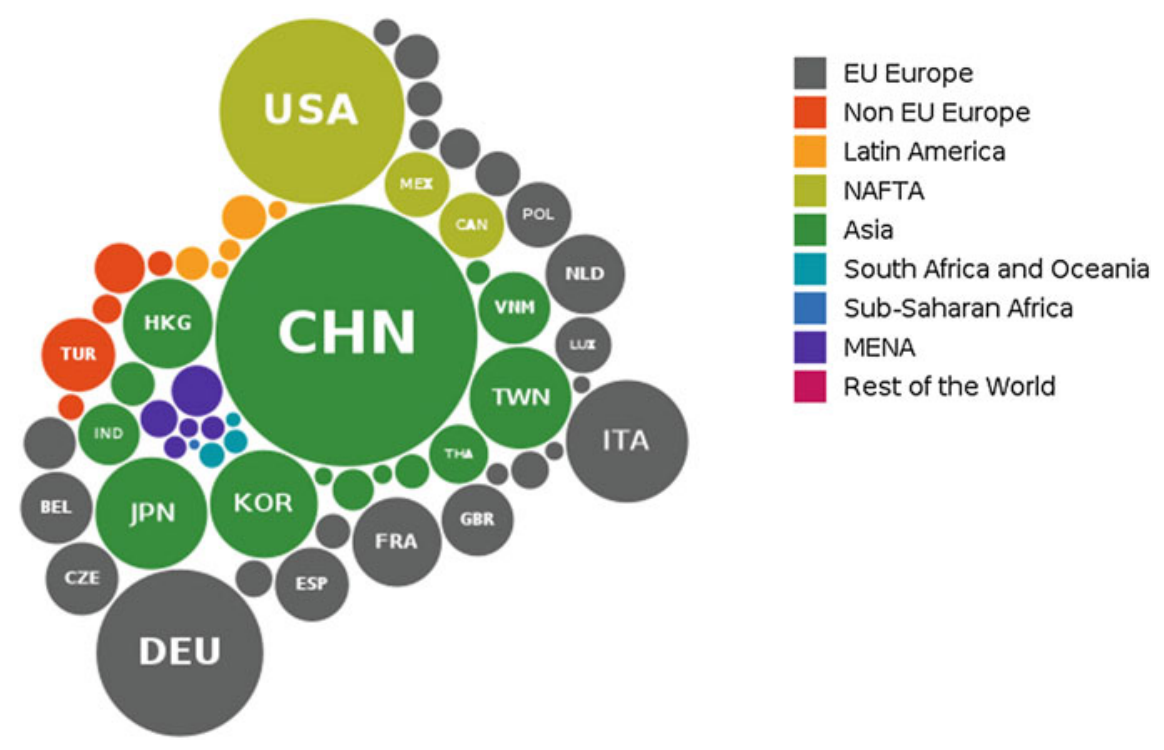

Fig. 2 World production of woven and non-woven fabrics for technical uses, year 2018. Source ExportPlanning (2018)

fabrics for technical uses is increasingly over 62 billions of Euros in 2018 where, besides China (14.6 billions) and USA ( 7.3 billions), in Europe, Germany (5.9 billions), and Italy ( 3.2 billions) are the most competitive countries (Fig. 2). The abovementioned technical textiles field aggregates the non-woven textiles (43\%), a wide range of impregnated, coated, or resin-based fabrics (23.3\%) useful for the textile architecture, and another significant variety of products and semi-finished technical textiles (15.6\%), while yarns, tapes, and labels for various industrial application cover the rest $18.1 \%$ of the cake (ExportPlanning 2018). Furthermore, a clustered area led by Germany and Italy appears the most competitive in Europe for the production of both of impregnated, coated, or resin-based fabrics (Fig. 3a) and other textile products and semi-finished technical textiles (Fig. 3b).

Impregnated, coated, or resin-based fabrics and polymeric foils (TPU, PVC, PTFE) for textile architecture and membrane structures represent surely a niche segment of whole textile market; nevertheless, their impact seems to be as much meaningful and valuable as it deals with the well-being of the final users, and with the long-lasting, performative and non-toxicity requirements at the same time.

Looking at the textile manufacturing sector as a whole, it is also clear that environmental sustainability is still a challenge to be faced and closing the loops thanks to the activation of the virtuous 5 Rs processes ${ }^{1}$ is still a dream to be built in the near future (Fig. 4). According to the estimation of European Commission, the EU textile

\footnotetext{
${ }^{1}$ Environmentalists all over the world profess 5 Rs in ensuring the reduction in solid waste pollution. These are Reduce, Re-use, Recycle, Replace or Remanufacture, and Recover.
} 


\section{(a)}
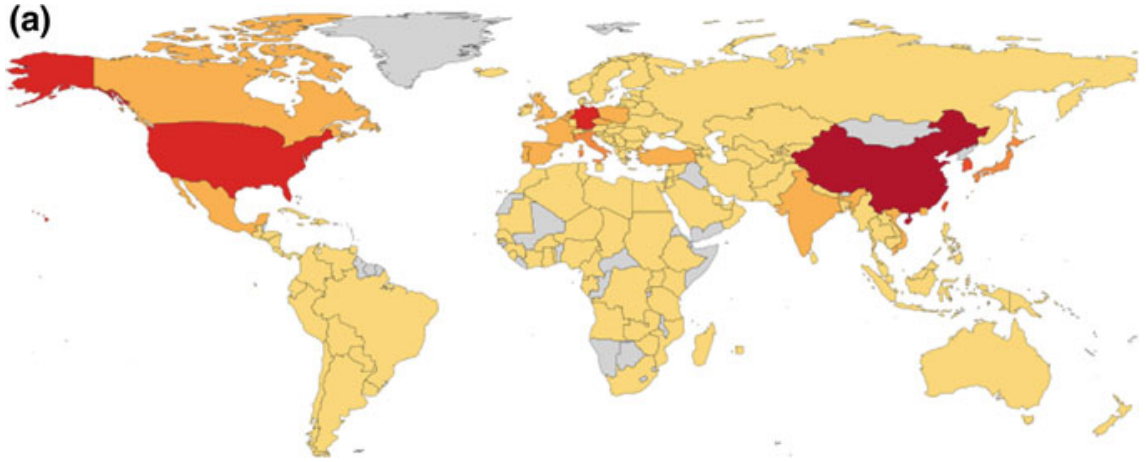

$\begin{array}{lllllll}0.0 & 0.1 & 0.3 & 0.6 & 0.8 & 1.2 & 6.0\end{array}$

Billions of euro

Source: Ulisse Information System

Country: ALL, Year: 2018, Economic Variable: X, Currency: EUR, Prod: UL590A00

(b)
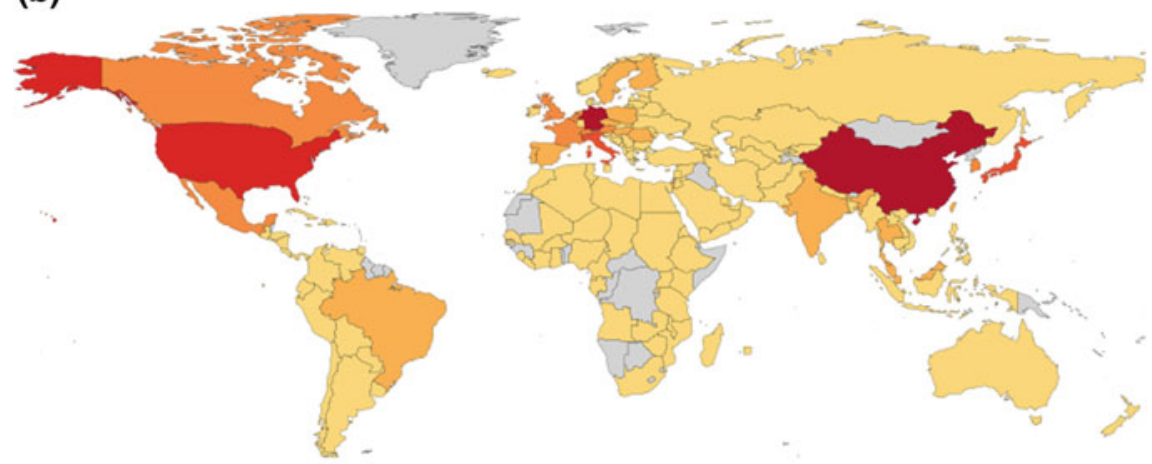

0

$\begin{array}{llllll}31 & 112 & 230 & 367 & 619 & 904\end{array}$

Millions of euro

Source: Ulisse Information System

Country: ALL, Year: 2018, Economic Variable: X, Currency: EUR, Prod: UL59A000

Fig. 3 Competitive position of Germany and Italy in the world production of technical textiles (a, left) and textile products for technical uses (b, right), year: 2018. Source ExportPlanning (2018) 


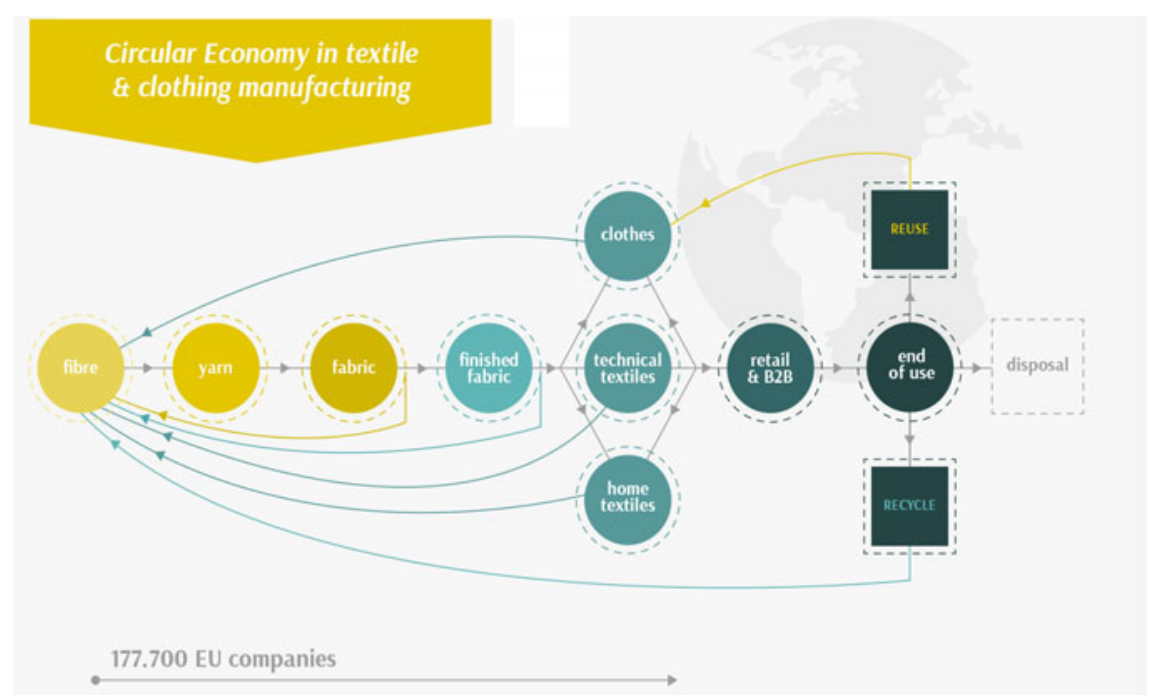

Fig. 4 Forecast scheme on how to make the European textile and apparel manufacturing sector circular. Currently, it is made of 177.700 companies, $99 \%$ of which are SMEs and all are involved in the production segment indicated by the arrow below (EURATEX 2019)

industry generates around 16 million tonnes of waste per year, most of which end up in landfills or incinerators. The quantity of clothes bought in the EU per person has incredibly doubled in a few decades, and now we buy an average of $13 \mathrm{~kg}$ of new clothes every year of which less than $1 \%$ is recycled in new clothing, while only that $13 \%$ of recycled textile materials go to other industries for use in lower-value applications such as insulation, mattress fillings, which are no longer recycled after use. The consumer use also has a large environmental footprint, due to the water, energy, and chemicals used in washing, tumble drying, and ironing, as well as micro-plastics shed into the environment (Euratex 2019; SAPEA, Science Advice for Policy by European Academies 2019).

Since 2018, United Nations Economic Commission for Europe has been working to the traceability for sustainable value chains in the textile sector, aiming to ensure that textiles are separately reusable/recyclable in all states by the 2025 at the latest (UNECE 2017).

\section{Bio-terminology for Textiles and Polymers Raw Materials}

With reference of Europe, more $60 \%$ of raw materials of woven and non-woven textiles are synthetic matters, made of fossil fuels and non-biodegradable, while the other $40 \%$ refers to natural fibers, although it must not be assumed that the latter's manufacturing processes are automatically "bio." It is well known that the 
bio-cotton can drastically reduce the environmental impact of conventional cotton, nevertheless the share of sustainable cotton increased from 6\% in 2012 to $19 \%$ in 2017. Derived from cellulose filaments made of dissolved wood pulp or other starches are covering less of $10 \%$ of the fibers utilized in the textile sector. Most of the raw materials used in textile industry are still polymers made of petroleum. A biopolymer includes various materials of natural origin, such as wood, cellulose, chitosan, and chitin (Chiellini et al. 2001). Thanks to the fast advances in the synthesis of renewable raw materials (surplus or waste products from agriculture or foresting) within sustainable processes via fermentation, using a special mix of microorganisms and bacteria- a wider number of biopolymers can be created. Most of them are not degradable or compostable, and thus, only few of them are really closing the loops. As with conventional plastics, biopolymers are available in many grades and with widely varying properties, which depend on the application. A clear distinction between bio-based and fossil-based plastics on one hand, and biodegradable on the other hand has been done by many scientists (Niaounakis 2015), nevertheless the list of each family of plastics truly compatible with the bio-economy is going to be updated, and hopefully implemented, in the near future. The crucial difference between fossil-based polymers and biodegradable ones is that the first family is resistant to degradation, while the latter, also named oxo-degradable polymers, can be decomposed by microorganisms in a measurable rate, which depends from three main factors - light, water, and oxygen - and increases with time, while only few are compostable, that is they degrade in a specific environment, yielding $\mathrm{H}_{2} \mathrm{O}, \mathrm{CO}_{2}$, biomass, and inorganic compounds, without leaving visual or toxic residue into the soil (Ashter 2016).

In conclusion, the bio-prefix also applicable to biodegradable synthetic polymers can be misleading as this category can lead to advantages at the end of life when compared to the plastics produced so far, but still remains unsustainable in the cradle, as they use non-renewable resources. Only natural polymers-biodegradable and bio-based biopolymers-promise a high level of eco-compatibility; they are much less of all the other polymers on the market, and several studies on the potentialities of the renewable feedstock, such as plants, animals, or microorganisms are ongoing. Innovative technologies start to emerge, enabling recycling textiles into virgin fibers, as in the case of: Infinited Fiber (Infinited Fiber Company 2019); Re.Verso ${ }^{\mathrm{TM}}$ spin-

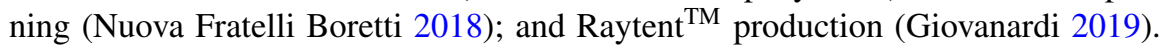
Nowadays, the greatest challenge is to succeed on the one hand in reducing the quantity of fossil-based textiles, and, on the other hand, to guarantee that finishing treatment-able to confer specific functionalities and technical uses-are also drastically re-developed toward the use of natural alternatives and energy-saving separation processes at the end of life. 


\section{Textile Architecture Today}

Textile architecture and its textile-based construction technology are characterized by the low weight of the embedded materials: around $0.2-0.5 \mathrm{~kg} / \mathrm{m}^{2}$ for transparent fluorpolymer systems up to $0.5-2 \mathrm{~kg} / \mathrm{m}^{2}$ for multilayer textile membrane systems, working in extreme loading condition. Fibers and polymer granulates should be combined in different ways, with the aim to create custom-made materials for textile architecture (Table 1). Nevertheless, this wide potentiality has not yet fully exploited by designers. As much as $90 \%$ of membrane structures are made of a limited range of flexible products, as PVC/Polyester, PTFE/Glass, Silicon/Glass, ePTFE (Tenara ${ }^{\circledR}$ ) or ETFE foils. The last ten years achievements have shown countless improvements in the ultra-lightweight construction, in terms of: (a) effectiveness and life-span durability of flexible materials; (b) the improvement of construction details and site-specific installation procedures; and (c) the hybridization of this younger building technology with the traditional ones, answering for various functionalities. Textile materials for architecture seem more and more reliable and durable, either used in the form of a flexible membrane, suitably coated, as well as soft formwork of rigid concrete-based (i.e., textile beton) or resin shells (i.e., GFRP), and both for temporary and permanent

Table 1 Fabrics and composite materials available for architectural use. The finished products are related to their production chain (in brown). Performances can be improved by the adding an optional treatment to the semi-finished product (drawing by the authors)

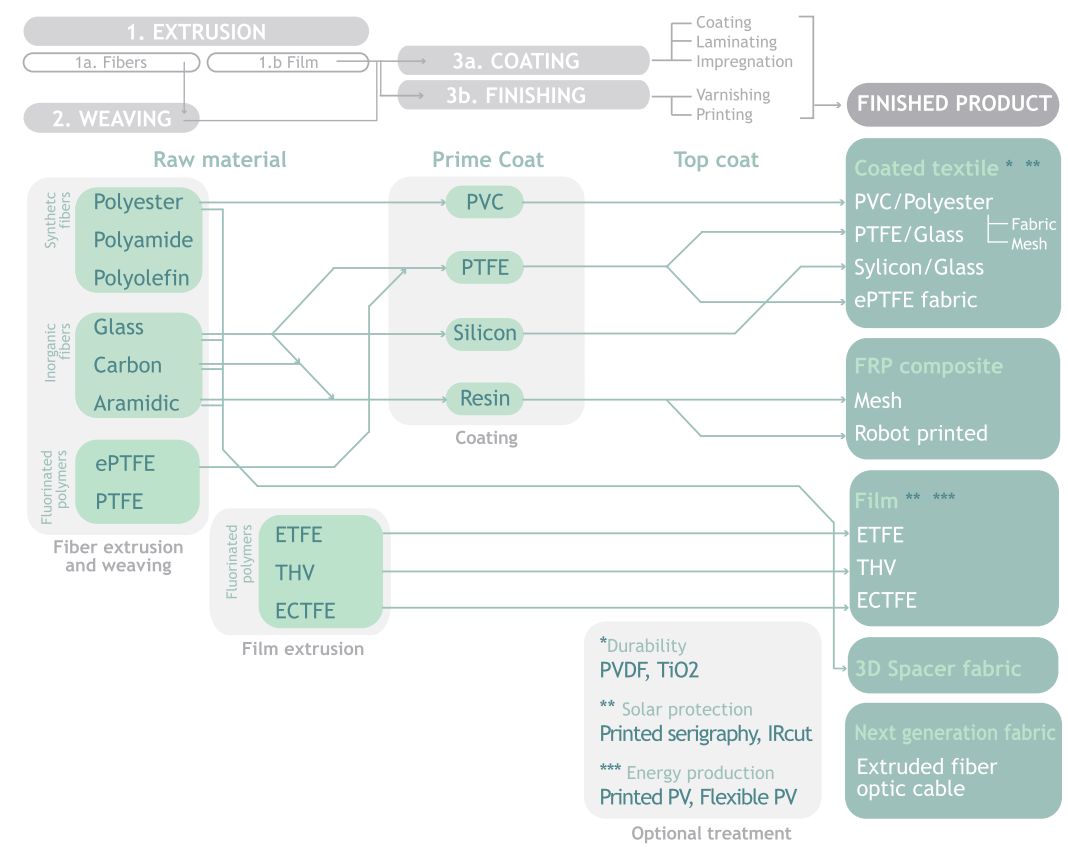


construction. Despite this, the specific sector of textiles and polymers still has a low market penetration in the wider predominant building components sector. In this scenario, innovation occurs more often led by novel designs and structural concepts at the macro-scale (building level) than by looking at the eco-sustainability of the textiles and polymers at the micro-scale (matter level).

After this decade of advances, harmonizing the local regulatory standards (Mollaert et al. 2016), and sharing knowledge through networks ${ }^{2}$ and multidisciplinary research projects, ${ }^{3}$ urgent open issues under scientists responsibility are: (1) a fairer and environmentally conscious design-driven innovation path; (2) the designers' lack of in-depth knowledge on membranes and foils; and (3) the gap between the increasing interest in innovative designs and the limited number of experimental testing laboratories.

\section{A Research-Integrated Design Methodology, Enabling Biotechnologies in Textile Architecture}

Since 2015, the multidisciplinary research laboratory TEXTILESHUB (TH Lab) at Politecnico di Milano has been carrying out, in a complementary and mutually reinforcing manner, design consultancies, educational exercises, and experimental scientific campaigns. The common goal of these theoretical and practical activities is assessing the applicability of novel natural/synthetic flexible materials, making progress in the creative and innovative use of ultra-lightweight building systems. Thanks to the different skills available at TH Lab (Table 2), its activity ranges from

Table 2 Interrelation of competences and activities carried out by the multidisciplinary Research Laboratory, with the aim to manage of the whole design to construction process of textile architecture (drawing by the authors)

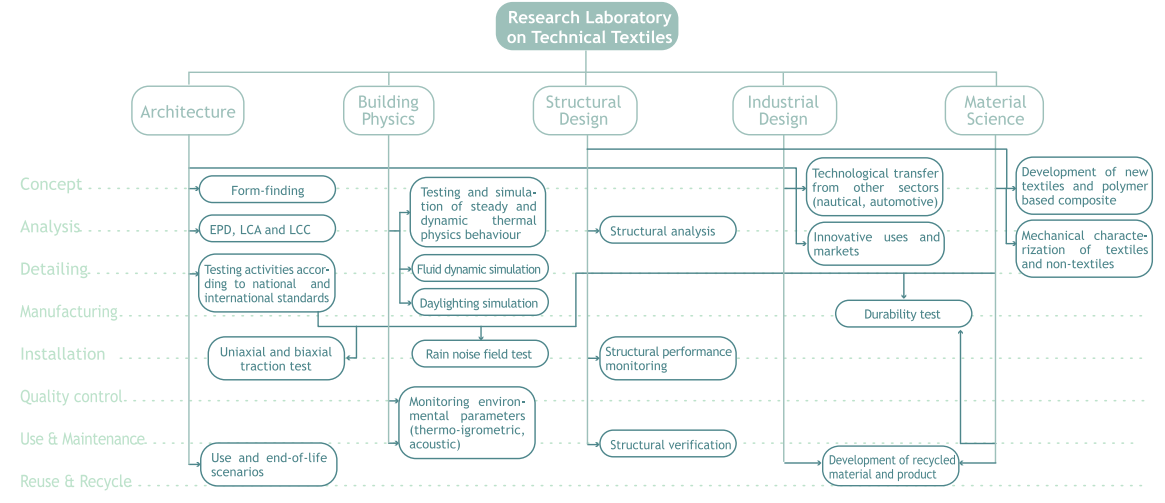

\footnotetext{
${ }^{2}$ TensiNet in Europe and Latin America; IFAI in USA, IASS around the world.

${ }^{3}$ Contex-T FP6 pr. (2006); COSTActions TU1303, CA17107; Innochain Project (2018).
} 
testing mechanical and optical behavior to measuring performances of membranes and composites. TH Lab also gives service to firms and manufacturers: From 2017, it is an accredited laboratory for uniaxial and biaxial tensile tests, under the signatory of ILAC mutual recognition agreements (Services Accredia 2019). Welding and sewing machines are there available for the researchers' prototyping activities.

The authors, who are members of TH Lab, adopt the methodological approach of architectural technology, which is essentially a systemic design approach applied to the built environment and in a multi-scale perspective, where the material choice plays a crucial role throughout the whole design process - in relation to the requirements and environmental constraints - and it strengthens the specialized disciplines-materials engineering, chemistry, building physics - to drive the innovation into the building sector (Meadows and Wright 2008).

We assume that textile-based membrane architecture is characterized by a medium-low degree of innovation as shown in respective workflows at top and bottom of Table 3 . Thanks to a research-integrated and iterative design approach, and an involvement of fabrics/foils producers and manufacturers during the whole design process, innovative loops can appear at multiple levels (the scheme center, Table 3). Nowadays, architects and designers need to cope with a full predictive control of the design-to-construction process. Through this data-driven methodologyin which experimental data constitute the input (i.e., breaking strength, elongation, tensile strength) needed to compute a reliable performance-based design-the $\mathrm{TH}$ Lab works as fruitful and disruptive bridging between different expertise at multiple scale. This iterative workflow of designing-prototyping-testing-scaling up is closely linked with the material characterizations of membrane and foil.

Due to this multidisciplinary and measure-centered research methodology, a set of novel bio-based coatings and natural fibers might be experimentally tested and validated at laboratory scale, foreseeing the real production. For example, the transfer of some bio-cellulosic products developed for the medical and packaging sectors might drive the innovation also in textile architecture. A first research path experimentally evaluating novel bio-based textiles should be focus on the stiffness, through five main steps: (a) the scope and the scale of the innovation through a concept design

Table 3 Multidisciplinary research path cross-linked to an experimental design process might pull innovation in textile architecture (drawing by the authors)

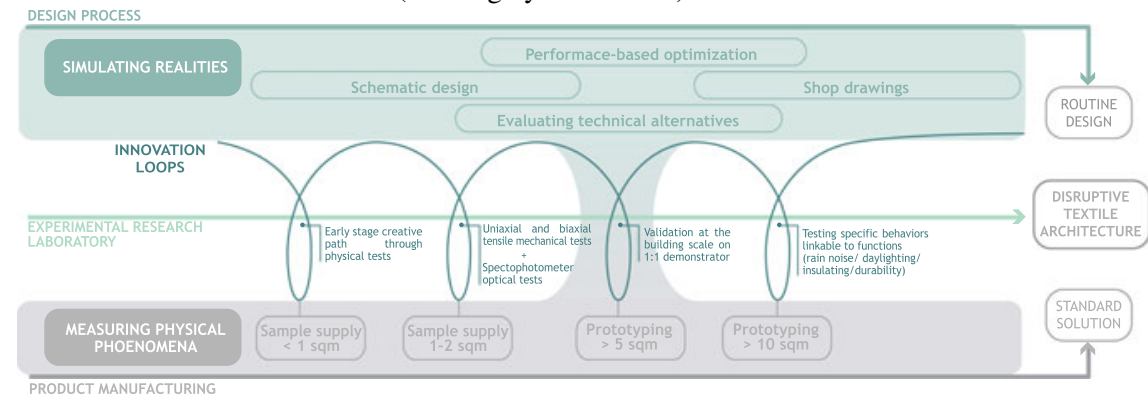


(form-finding); (b) the material characterization through the mechanical testing and continuous cross-validation of finite element modeling (FEM) tools; (c) physical testing the new materials' durability; (d) scaling up the investigation at the architectural concept, through FEM, life cycle assessment and thermal analysis; and (e) finalize shop drawings and real-scale demonstrators.

\section{Life Cycle Assessment for Textiles: Comparing the Eco-Efficiency of Bio-based and Fossil-Based Fabrics}

In the product and process development of more eco-friendly coated textiles, or a woven or non-woven membrane for architectural application, a double verification of their eco-efficiency (matter level) and environmental performances (building level) is in parallel needed. The LC analysis phase, as appears in Table 2, can provide an early stage evaluation of environmental impacts of a novel design concept and/or a material choice assumption. At that stage, a comparative LCA allows, on one hand, to check the environmental impacts generated during the production of alternative materials, on the other hand, to deepen the eco-profile's incidence of different technical solutions. A building level LCA investigation takes into account the efficiency of the whole system, the efficacy of the foreseeing construction procedures, the structural and thermo-physic and acoustic performances, as well as the costs. In the road map of the eco-efficiency of textiles for architecture, different stakeholders can be associated to the life cycle steps, above all: the chemical industry and the producers of polymeric/bio-based/biodegradable yarns and fabrics, on one side, and the supply companies of tailoring and assembly of the membrane components for the architecture to the other.

The considered scientific sources on the environmental impact assessment of textile and finishing industries clearly show that the investigation of the environmental impacts of the textile industry for clothing, furniture cladding and internal architecture has been started some decades ago, while the interest of the environmental burden of coated membranes and films for architecture starts recently. In general, literature surveys and other LCA studies on textiles show that most of the available process data are still not fully readable and clearly outliers. At the material's production level, TU Delft provided an up-to-date insight into the environmental burden of cotton, polyester, nylon, acryl, and elastane-based textiles (Van der Velden et al. 2014). The Institute of Textiles at Hong Kong Polytechnic developed a way to quantify and rank the ecological sustainability of textile fibers, such as organic cotton, flax, viscose, polyester, polypropylene, acrylic, and nylon (Smith and Barker 1995). The eco-efficiency of textile wet processing in Finland was also studied, as a part of drafting the Best Available Technique Reference documents for the European IPPC Bureau (Bidoki and Wittlinger 2010). Since 2004, Swedish Chalmers University of Technology has been focusing on LCA of textile products used for furniture wrapping (Subramanian et al. 2012), contributing at the adaptation of the LCA methodology 
to the textile sector specificities, and identifying the basis for a simplified evaluation tool, useful for textile companies. The EU COST Action 628 tried to define the best available technology (BAT) of textile processing and eventually suggested criteria for ISO (Type III) Environmental Product Declaration (EPD) standards (Kalliala and Talvenmaa 2000). In the field of textile architecture, the authors, as leaders of the Sustainability and LCA working group of a European project focused on the sustainability improvement of structural textiles (COST Action TU1303 2017), are working on the development of EPDs of membranes and foils, as well as defining their data quality requirements, transferable into Product Category Rules (PCR) documents. Furthermore, a significant eco-design approach for textile architecture can pass from the definition of brief design principles for weight reduction and the efficient of formstructure membrane skins (Monticelli and Zanelli 2019). The TAN group's authors collaborated with EU-funded EASEE project, assessing the environmental impacts of various textile finishing layers for inner walls, considering to cover an area of $3 \mathrm{~m}^{2}$ as functional unit (Masera et al. 2017). A wide range of textile-based wallpapers and other less flexible finishing solution was then analyzed. Basing on this documented comparison between nature-based and fossil-based textiles (Table 4), the complexity of the LCA approach clearly tends to increase if we do not only look at the production of a new bio-textile-compared to a fossil-based one-but we want to measure its eco-efficiency throughout its service time and final disposal. This comparative LCA needs to: (a) identify key parameters and phases in the whole life cycle aiming to an improvement of the ecological efficiency of the product; (b) optimize the life cycle stage in relation to various disposal scenarios (recycling, incineration, landfill); and (c) carry out an life cycle costing (LCC) evaluation to identify the main cost contributions of the new bio-based textiles and find ways to optimize them.

\section{Conclusion}

The essay started from the methodological assumption that today it is relevant more than ever for designers to experiment with the matter-and its performance-of the architecture, from the early stages of the creative process. Possible knowledge gaps and innovation lacks that limit the spread of bio-based materials and sustainable circular processes in textiles architecture might be urgently overcome. In this specific building segment, due to the peculiarity of its short and effective from design-toconstruction value chain-novel concepts of green products and processes would involve as much as designers, producers, and manufacturers, which should work in parallel, with an high level of exchange of information and cross-verification along the whole iterative process. The presumption that the environmental benefit of a specific material may simply be associated with its natural origin is especially dangerous in the textile architecture field, where textile-based composites and polymeric fabrics are still predominant. This is why the authors stated the need of overlapping quantitative and qualitative tools for assessing the environmental sustainability, referring to life cycle assessment methodology. Eventually, the TH Lab research-integrated 
Table 4 Different textile inner finishing layers-LCA results

\begin{tabular}{l|c|c|c|c}
\hline Impact category & $\begin{array}{l}\text { Cotton textile } \\
360 \mathrm{~g}\end{array}$ & $\begin{array}{l}\text { Kenaf textile } \\
350 \mathrm{~g}\end{array}$ & $\begin{array}{l}\text { Polyester textile } \\
400 \mathrm{~g}\end{array}$ & $\begin{array}{l}\text { PVC textile 380 } \\
\mathrm{g}\end{array}$ \\
\hline $\begin{array}{l}\text { Abiotic } \\
\text { depletion (kg Sb } \\
\text { eq) }\end{array}$ & 0.0115 & 0.0014 & 0.0051 & 0.00461 \\
\hline $\begin{array}{l}\text { Acidification } \\
\text { (kg SO }{ }_{2} \text { eq) }\end{array}$ & 0.0183 & 0.0016 & 0.0020 & 0.0041 \\
\hline $\begin{array}{l}\text { Eutrophication } \\
\text { (kg PO4-eq) }\end{array}$ & 0.0038 & 0.0013 & 0.0010 & 0.0007 \\
\hline $\begin{array}{l}\text { Global warming } \\
\text { GWP100 (kg }\end{array}$ & 1.9302 & 0.2393 & 0.7110 & 0.6800 \\
CO eq) & 0.000000041 & 0.000000011 & 0.000000092 & 0.000000027 \\
\hline $\begin{array}{l}\text { Ozone layer } \\
\text { depletion (ODP) } \\
\text { (kg CFC-11 eq) }\end{array}$ & 0.7634 & 0.1077 & 0.6625 & 0.3969 \\
\hline $\begin{array}{l}\text { Human toxicity } \\
\text { (kg 1,4-DB eq) }\end{array}$ & 0.9811 & 0.1042 & 0.1582 & 0.1206 \\
\hline $\begin{array}{l}\text { Freshwater } \\
\text { aquatic ecotox } \\
\text { (kg 1,4-DB eq) }\end{array}$ & 0.0006 & 0.000043 & 0.00017 & 0.00019 \\
\hline $\begin{array}{l}\text { Marine aquatic } \\
\text { ecotoxicity (kg } \\
1,4-D B \text { eq) }\end{array}$ & 915.9794 & 210.4671 & 333.6373 & 234.1596 \\
\hline $\begin{array}{l}\text { Terrestrial } \\
\text { ecotoxicity (kg } \\
1,4-D B \text { eq) }\end{array}$ & 0.0739 & 0.00056 & 0.0022 & 0.0038 \\
\hline $\begin{array}{l}\text { Photochemical } \\
\text { oxidation (kg } \\
\mathrm{C}_{2} \mathrm{H}_{4} \text { eq) }\end{array}$ & 0.6076 & 12.0287 & \\
\hline $\begin{array}{l}\text { Non-renewable, } \\
\text { fossil (MJ eq) }\end{array}$ & 20.6502 & & & \\
\hline & & & & \\
\hline
\end{tabular}

design approach and its focus on LCA of textiles were presented, together with a comparative study of the environmental impacts of fuel-based and nature-based fabrics, used as finishing layer of a wallpaper in interior architecture.

\section{References}

Ashter, S. A. (2016). Introduction to bioplastics engineering. Plastic Design Library Handbook Series, Elsevier Ltd. https://doi.org/10.1016/B978-0-323-39396-6.00011-7.

Bidoki, S. M., \& Wittlinger, R. (2010). Environmental and economical acceptance of polyviniyl chloride (PVC) coating agent. Journal of Cleaner Production, 18, 219-225. 
Chiellini, et al. (2001). (Eds.), Biorelated polymers: Sustainable polymer science and technology. Kluwer Academic Plenum Publishers.

COST ACTION TU1303. (2013-2017). Novel structural skins-improving sustainability and efficiency through new structural textile materials and designs. http://www.novelstructuralskins.eu.

ExportPlanning. (2018). Ulisse information system. http://www.exportplanning.com/analytics/ png/.

EURATEX, The European Apparel and Textile Confederation. (2019). Prospering in the circular economy. Available at https://euratex.eu/wp-content/uploads/2019/01/EURATEX_CE_policy_ brief_LR.pdf.

Giovanardi. (2019). Raytent: Recycled acrylic yarns, Italy. Available at https://www.raytent.it/home. Infinited Fiber Company. (2019). Finland. Available at https://infinitedfiber.com.

Innochain Project. (2018). CITA, School of Architecture, Copenhagen. http://innochain.net/about/. Kalliala, E., \& Talvenmaa, P. (2000). Environmental profile of textile wet processing in FinlandTampere University of Technology, Finland. Journal of Cleaner Production, 8(2000), 143-154.

Masera, G., Ghazi, W. K., Stahl, T., Brunner, S., Galliano, R., Monticelli, C., et al. (2017). Development of a super-insulating, aerogel-based textile wallpaper for the indoor energy retrofit of existing residential buildings. Procedia Engineering, 180, 1139-1149. https://doi.org/10.1016/j. proeng.2017.04.274.

Meadows, D. H., \& Wright, D. (2008). Thinking in systems. Chelsea Green Publisher.

Mollaert, M., Dimova, S., Pinto, A., \& Denton, S. (Eds.). (2016). Prospect for European guidance for the structural design of tensile membrane structures. Support to the implementation, harmonization and further development of the Eurocodes. JRC Science Hub, European Union. https:// doi.org/10.2788/967746.

Monticelli, C., \& Zanelli, A. (2019). Eco-design principles for a preliminary eco-efficiency assessment in the design phase: Application on membrane envelopes. In Zanelli et. al. (Eds.), TS19 Proceedings (pp. 280-291). Politecnico di Milano, June 3-5, 2019. https://doi.org/10.30448/ ts2019.3245.41.

Niaounakis, M. (2015). Biopolymers: Applications and trends. Oxford: Elsevier.

Nuova Fratelli Boretti. (2018). Filatura C4 and Re.Verso ${ }^{\text {TM }}$. http://www.filaturac4.it/progetto-reverso/.

SAPEA, Science Advice for Policy by European Academies. (2019). A scienti c perspective on microplastics in nature and society. Berlin: SAPEA. https://doi.org/10.26356/microplastics.

Services Accredia. (2019). Accreditation certificate of Politecnico di Milano-Interdepartmental Laboratory TEXTILES HUB, Testing Laboratory 1275 G. www.services.accredia.it, http://pa. sinal.it/283012.pdf.

Smith, G. G., \& Barker, R. H. (1995). Life cycle analysis of a polyester garment. Resources, Conservation and Recycling, 14, 233-249.

Subramanian, S. M., Hu, J. Y., \& Mok, P. Y. (2012). Quantification of environmental impact and ecological sustainability for textile fibres. Ecological Indicators, 13, 66-74.

UNECE. (2017). TEXTILE4SDG12: Transparency in textile value chains in relation to the environmental, social and human health impacts of parts, components and production processes. United Nations. https://www.unece.org/fileadmin/DAM/trade/Publications/ECE-TRADE-439ETEXTILE4SDG12.pdf.

Van der Velden, N. M., Patel, M. K., \& Vogtländer, J. G. (2014). LCA benchmarking study on textiles made of cotton, polyester, nylon, acryl, or elastane. The International Journal of Life Cycle Assessment, 19(2), 331-356. 
Open Access This chapter is licensed under the terms of the Creative Commons Attribution 4.0 International License (http://creativecommons.org/licenses/by/4.0/), which permits use, sharing, adaptation, distribution and reproduction in any medium or format, as long as you give appropriate credit to the original author(s) and the source, provide a link to the Creative Commons license and indicate if changes were made.

The images or other third party material in this chapter are included in the chapter's Creative Commons license, unless indicated otherwise in a credit line to the material. If material is not included in the chapter's Creative Commons license and your intended use is not permitted by statutory regulation or exceeds the permitted use, you will need to obtain permission directly from the copyright holder.

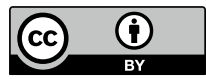

